\title{
Consumption and Trade of Wheat and Flour in Pakistan - The Role of Public and Private Sectors
}

\author{
Peter A. CORNelisse and HaNS de KrUiJK*
}

\begin{abstract}
This article, the second of two articles in this Review on the operation of the wheat market in Pakistan, ${ }^{1}$ describes the various sources from which consumers in the Punjab, Sind and the NWFP obtain wheat and flour. There appear to be considerable differences in the patterns of wheat provisioning, if consumers are distinguished by province, rural and urban areas and household income. Further, an evaluation is made of the performance of private traders in wheat- and flourmarkets. These findings are then used to examine whether the position of selfsufficiency in wheat, which the country has recently achieved, provides arguments for revising the wheat-market policies adopted during a period when the situation was much less favourable.
\end{abstract}

\section{INTRODUCTION}

In the beginning of the 1980s, Pakistan achieved near-self-sufficiency in wheat. Such situations had seemed to be within reach in the Seventies also, especially in 1970-71 and 1976-77, when imports fell to a mere five percent of the domestic production or less. Since the most recent harvests have not been good, necessitating increased imports, one wonders if history is not repeating itself. After all, the high growth rate of the population of Pakistan puts a continuous pressure on wheat production. While the considerable increase in wheat yield since the 1960 s, assisted by an increase in the area under wheat, improved the wheat supply from domestic sources, the level of annual average wheat consumption remained between $130 \mathrm{~kg}$ and $140 \mathrm{~kg}$ during the last 15 years.

*The authors are Professor of Development Planning and Lecturer, respectively, at Erasmus University, Rotterdam. They gratefully acknowledge a very valuable exchange of views with Professor Syed Nawab Haider Naqvi during the preparation of this article. This article is based on a study jointly carried out by staff members of Erasmus University, Rotterdam, and the Pakistan Institute of Development Economics, Islamabad, with financial support from the Dutch Ministry for Development Co-operation.

${ }^{1}$ The first article describes in some detail the various uses farmers have for wheat and the flows of wheat from farmers, via traders, to various categories of consumers in the Punjab. See P. A. Cornelisse [2]. 
However, the present situation differs in two ways from that in the past. Firstly, very considerable wheat stocks $-2,188$ thousand tons in 1983-84 [14 p. 88], i.e. nearly 20 percent of production, or about 45 percent of the marketed surplus - have meanwhile been built up. Secondly, as production of wheat has grown at a significantly higher average rate than wheat consumption, the gap between structural production and consumption has narrowed further with the passage of time. In fact, time-series analysis suggests that this gap has now fallen to zero. ${ }^{2}$ Therefore, even though the lesson from the past is one of caution, the present wheat supply situation can be viewed with more optimism than was permissible 10 or 15 years ago.

Most of the wheat-market policies prevailing in Pakistan were initiated during the period when the balance of domestic supply and demand for wheat still showed a relatively large deficit. One of the principal policy concerns then was to secure the supply of wheat to all households living outside wheat-producing areas. To this end, a general flour-ration system was set up providing flour at subsidized prices without discrimination, next to open markets of wheat and flour where prices were determined freely. Under the present conditions, however, such a general ration system seems no longer needed. Yet, if it is simply abandoned, poor households, stripped of an alternative to the open market for their supply of wheat or flour, would be severely hurt. This provides a strong rationale for a selective ration system aimed at providing flour at concessionary prices to the poor in the case of an abolition of the prevailing system.

Elaborating on this, one of the main purposes of this paper is to estimate the volume of wheat required in order to maintain a selective ration system under different assumptions regarding the level of the poverty line (Section 4). In order to prepare the ground for these estimates, Section 2 presents an analysis of the sources of wheat and flour for the categories of consumers differentiated by area of residence and by level of income. Further, an attempt is made in Section 3 to evaluate the activities of private wheat traders. Suppose that a structural change in the ration system and a diminished need to augment the national wheat stock reduce the volume of wheat to be procured annually by the State. By itself such a development may be desirable as it releases funds which the State can use for socio-economic development. The question then is, however, in which ways a limited withdrawal by the State from the wheat market will affect the functioning of that market. For an answer to that question it is at least useful to know how private traders function at present.

Most of the data used in the present article have been obtained by means of a survey (henceforth referred to as the Survey) carried out in May and June 1982 in the context of a joint research project of Erasmus University Rotterdam and the

${ }^{2}$ See Cornelisse and Kuijpers [3] for an empirically tested function of structural wheat
Pakistan Institute of Development Economics. The Survey consisted of a series of enquiries among farmers, traders, millers, ration shopkeepers and consumers in the Punjab, Sind and the NWFP. As these groups of actors follow each other in the wheat-trade chain, each set of transactions, corresponding with one stage in the trade chain, was viewed from the side of buyers and sellers. This provided useful opportunities for verifying statements by individual actor groups. For more information about the Survey, see Cornelisse and Naqvi [4]

The policy measures briefly indicated above are only a part of the measures which affect the production, trade, processing and consumption of wheat in Pakistan. It will not be necessary to provide here a full description of all of them. But, by way of an introduction to the following sections, some additional information about the nature and magnitude of some of them will be useful. Firstly, a State monopoly on wheat imports and exports insulates the domestic market from the international market. A network of procurement depots allows procurement of massive volumes of wheat constituting, in recent years, approximately three quarters of the national marketed surplus. The wheat thus obtained is used for three purposes. One part about a half million ton per year during the period from 1979-80 to $1982-83$ - goes into augmentation of the buffer stock. ${ }^{3}$ Another, larger, part is processed and subsequently distributed among ration shops where it is sold to ration-card holders at a subsidized price. And a third part is sold in the open market in the off-season to dampen seasonal price rises.

When farmers and traders sell wheat to procurement depots, they do so voluntarily. So, the impressive share of procured wheat in the total marketed volume of wheat provides convincing testimony to the attractiveness of the fixed procurement price for sellers in the Pakistan wheat market. Yet, it must be underlined that, since the early 1970 s, this price has been 25 percent to 45 percent below the price of imported wheat - and probably more if account is taken of the undervaluation of foreign exchange implicit in the rate of exchange. This situation benefits consumers at the expense of wheat producers and creates in fact an implicit income transfer from the latter to the former. This transfer has been estimated at Rs. 1,750 million for $1982-83 .^{4}$

A description of trade and consumption of wheat and flour in Pakistan in aggregate terms cannot be satisfactory as it conceals considerable differences between the various provinces. The figures in Table 1 can serve as an illustration. They show, among other things, that the Punjab produces a wheat surplus, Sind is approximately

${ }^{3}$ In $1983-84$, the increase of wheat stocks was only 180,000 tons.

${ }^{4}$ See Cornelisse and Naqvi, [4, Table 9.2]. Gotsch and Brown [5] arrive at estimates of Rs. 2,089 million and 1,540 million for the same transfer in 1975 and 1976, respectively. 
Table 1

Volumes of Production, Procurement, Releases and Consumption by Province, 1981-82 or $1982-83$

('000 Tons)

\begin{tabular}{lrrrcc}
\hline & Punjab & Sind & NWFP & Baluchistan & Pakistan \\
\hline Production & 7,798 & 2,062 & 962 & 318 & 11,140 \\
Marketed surplus & 3,350 & 825 & 310 & n.a. & n.a. \\
Procurement & 2,479 & 604 & 21 & 27 & 3,131 \\
Releases & 926 & 706 & 625 & 198 & 2,454 \\
Consumption & 6,245 & 2,120 & 1,710 & n.a. & n.a. \\
$\quad$ (i) of wheat & 4,665 & 1,390 & 800 & n.a. & n.a \\
(ii) of ration flour & 830 & 210 & 90 & n.a. & n.a. \\
(iii) of market flour & 750 & 520 & 820 & n.a. & n.a. \\
\hline
\end{tabular}

Note: (a) Production figures relate to 1981-82, and have been taken from [14]

(b) Figures on Procurement and Releases relate to 1982-83, and have been taken from [12].

(c) Figures on Marketed Surplus and Consumption of wheat ration flour and marketed flour relate to 1982-83, and have been taken from our own Survey.

(d) The figure of Releases for Pakistan as a whole excludes 328,000 tons for Azad Kashmir and Defence.

(e) n.a. means that figures were not available.

self-sufficient, but the NWFP and Baluchistan have a deficit. In 1982, it was still the exclusive responsibility of the State to reach a balance between production and consumption in each province because at that time the ban on private trade of wheat between provinces still prevailed. It also follows from the table that in the Punjab and Sind the amounts of wheat handled by private traders only, represented by the respective differences between marketed surplus and volume of procurement, are fairly limited. In fact, they are smaller than the amounts of wheat channelled by traders towards the procurement system. ${ }^{5}$ This can easily be seen, as just over half the amount of wheat procured is obtained from farmers. In the NWFP, however, the volume of procurement is negligible; in that province the flow of wheat handled by private traders only is limited by the marketed surplus. Further, the volumes of flour traded in the open markets in Sind and the NWFP appear to surpass the volumes of wheat handled in these provinces by private traders only. This indicates that most of this flour is purchased from the State which, in the case of the NWFP, moves it in from the Punjab. The flour bought in Sind by private traders from State organizations originates mostly from within that province.

${ }^{5}$ For a description of the intricate pattern of wheat-trade flows in the Punjab, see Cornelisse, [2].

\section{THE CONSUMPTION OF WHEAT (FLOUR)}

This section addresses itself to the following questions:

(i) What are the levels of wheat(flour) consumption per head in different provinces, in urban and rural areas and for different household-income groups?

(ii) From which sources and in what proportions do these groups of consumers obtain their wheat and flour?

(iii) What are the ruling prices of wheat and flour in the various markets?

Table 2 presents volumes of consumption of wheat(flour) per head by location and by income classes. The figures in the last column show that wheat consumption per head is consistently higher in rural areas than in urban areas. The difference is particularly pronounced in Sind, much more pronounced, in fact, than the corresponding difference observed in the 1979 Household Income and Expenditure Survey.

As a necessary goods, wheat is consumed in Pakistan in cosiderable quantities even by lwo-income households. But the very nature of the product does no stimulate an increase in demand for wheat beyond a level of consumption per head required for a standard diet. Hence, the relation between human consumption of wheat and income by households cannot be expected to be strong. ${ }^{6}$ Indeed, corre lation between the two variables based on our Survey figures appeared to be in significant, even though a wide variety of functional forms have been tested. This finding may be somewhat surprising, as the figures in some rows of Table 2 vaguely hint at patterns which differ with regions, but then it must be added that consump tion of wheat per head varies so widely even among consumers in the same class of income that the mean values presented in Table 2 are not statistically reliable.

On the other hand, the Survey data show clearly that different consumer groups obtain wheat and flour from different sources. In fact, as the figures presented in Table 3 illustrate, acquisition patterns of wheat appear to differ between consumer groups in different provinces, areas and classes of income. Take, for example, own farming which, for the country as a whole, is the most important single source of wheat. First, in all regions consumption from own farming is positively related with income: lower-income groups grow less wheat for own consumption than higher income groups, because, of course, poor households typically have

${ }^{6}$ It has been argued by Mellor [7], however, that, with increasing income per head, demand for high-protein food rises significantly, so much so that the derived demand for grains used as fodder also goes up. Indeed, policy-makers may well be taken by surprise by this additional wave of demand, because it tends to build up only after a slackening of demand for grain for human consumption. But also regression analysis of wheat consumption and income per head for a wide variety of countries does not reveal a significant relation, because of the influence o substitutes of wheat in human and animal consumption (see Opdam and Cornelisse [9]) 
less own or rented land available than is owned or rented by richer households. Further, and for obvious reasons, 'own farming' is a more important source of wheat in rural areas than in urban areas. Yet the share of own farming is remarkably high in urban areas, especially of the Punjab. The explanation is that 'own farming' really stands for obtainment of wheat free of charge from family farms operated by relatives, or from own land tilled by tenants. This observation illustrates the strong relations which still exist between the urban population and the agricultural sector. Finally, mainly as a result of differences in tenure systems, the relative importance of 'own farming' also appears to differ among provinces.

Wheat acquisition through wages in kind is only relevant in rural areas. In this case, there is a strong, negative relationship with income, which is, of course, precisely as one expects it to be.

Hardly any wheat is bought in the open market by consumers in rural and urban areas of the NWFP and Sind, but the underlying reasons are different for these two provinces. The marketed surplus of the wheat crop is of little importance in the NWFP, where wheat is mainly produced for own consumption. In Sind, on the other hand, a considerable amount of wheat does indeed reach the market, but most of that is absorbed by the procurement system (see Section 1). Thus, only a relatively thin flow remains for sales to the private sector, in which consumers form only a minor group. Note, however, that the Punjab has a substantial open market for wheat.

Trade in flour in the open market is of little importance in the Punjab. There are two reasons for this. Firstly, the Punjab is a wheat-surplus area, where a very considerable amount of wheat is still available for transactions in the open marke even after making provisions for own consumption and procurement. Secondly, although the rural Punjab is therefore relatively well provided with wheat, it obtains substantially more ration flour than is obtained by the rural areas of Sind and the NWFP. In the absence of open-market wheat and ration flour in rural Sind and rural NWFP, the only sources of wheat(flour) in these areas are 'own farming', wages in kind and open-market flour which, in fact, provide more than 90 percent of the amount of wheat and flour consumed there.

For the nation as a whole the share of ration flour in wheat and flour consumption in only about 10 percent. Even in urban areas, ration shops supply less than one third of total consumption, whereas almost no ration flour is sold in rural areas, except in rural Punjab. This is not due to lack of demand for ration flour. On the contrary, in response to a question in the Survey many respondents in rural Sind and rural NWFP complained about the absence of ration shops, or, when ration shops were present in these areas, about defective supplies from those shops. Another reason for the relatively low share of ration flour is the limited size of the twoweekly ration of $2.4 \mathrm{~kg}$ for persons aged 10 years or more and half that amount 
for those younger than 10 years. This amount clearly falls short of the average consumption of wheat and flour. Table 3 further shows that in the Punjab and in (he NWP ration flour is purchased by households of al urban areas of Sind and the NWFP ration flour income groups, although lower-income groups buy taticly more ration flou than other groups. In this regard, it is remarkable that the poorest in urban areas consistently buy smaller shares than those bought by groups slightly better off. The explanation may be found in the fact that the ration system allows a family only one purchase every two weeks. This relatively large expense may strain the financial position of the urban poor too heavily to allow them full use of their If this argument is correct, measures are to be taken to redress this shortcoming in the system (see Section 4). The urban poor now seem to be forced to buy so much flour in the open-market - at a considerably higher price - that, in terms of proportions of market flour in total wheat consumption, they are on a par with income groups at the other end of the scale.

The relevance of the distinction made above between various sources of wheat resides, of course, in the considerable differences between them in terms of reliability and price. Information on the latter aspect is presented in Table 4 which contains prices of wheat and flour for the six areas as reported by consumers. It shows, among other things, that the open market price of wheat for consumers in the Punjab and in Sind is, on average, about 10 percent higher than the procurement price. The wheat price is much higher in the NWFP than in the Punjab and in Sind, but the amount of wheat sold to consumers in the NWFP is very small.

The difference between the open-market price of flour and the price of ration flour cannot be attributed entirely to subsidies because of the difference in quality For example, 78 percent of the households in the Survey judged the quality of ration flour to be worse or much worse than that of open-market flour. In the Punjab the price difference is rather small but in Sind and the NWFP the open-market price of flour is much higher than the price of ration flour (about 30 percent, on average). Worse still, in these provinces the greatest part of the rural population has no access to flour from ration shops at all. This implies that those households in rural areas of the NWFP and Sind who do not have wheat from 'own farming' - and most of these households belong to the lowest-income groups in the country - have to buy highpriced flour from the open-market. In other words, the poorest households tend to pay the highest prices for their chapatis (coarse unleavened breads in the form of flat thin cakes).

\section{AN EVALUATION OF THE PRIVATE WHEAT TRADE}

The concept of "market efficiency", although basic in economics, is in reality

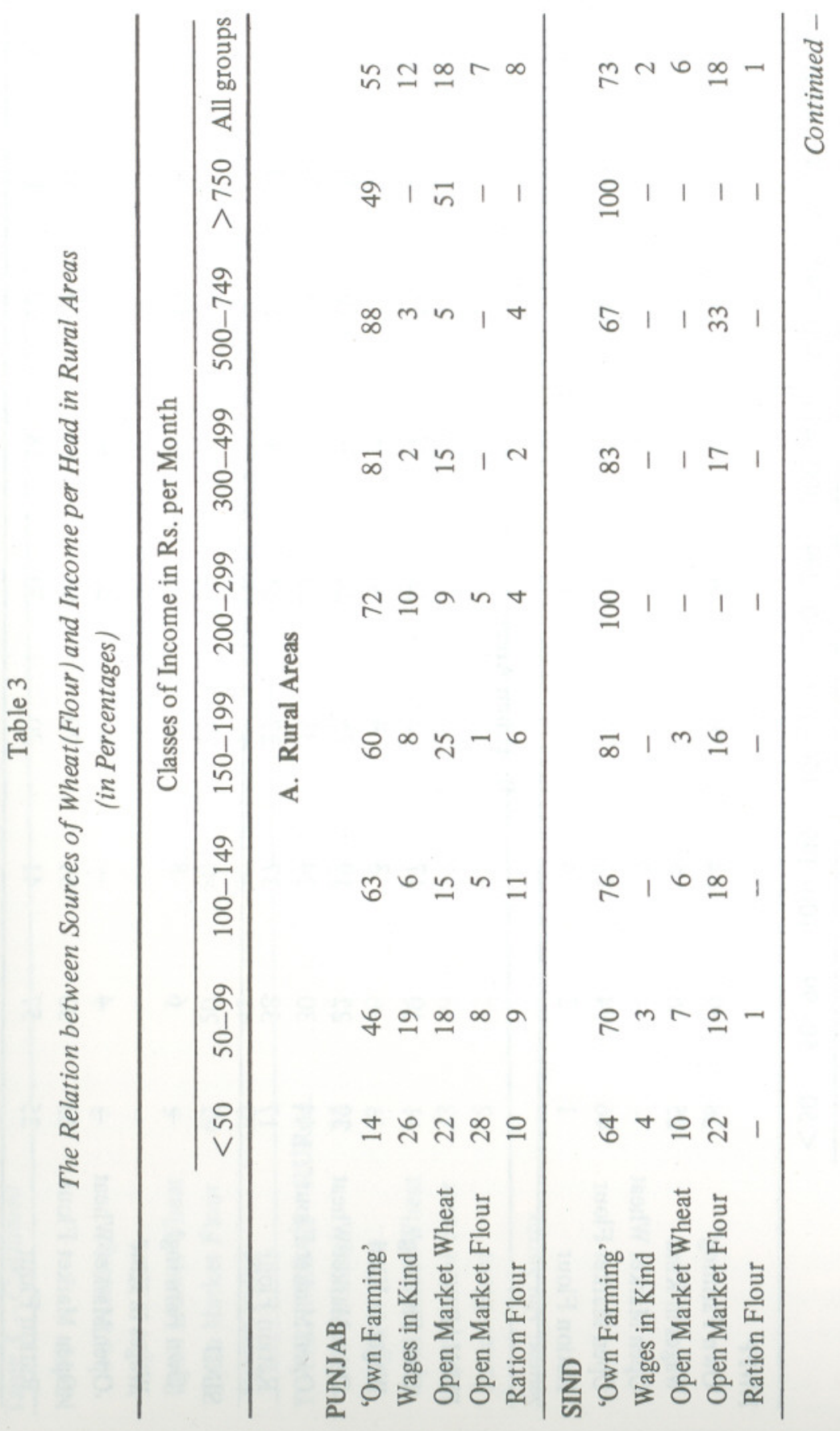
difficult to apply to test the operation of a specific market. There is not a single 
Classes of Income in Rs. per Month

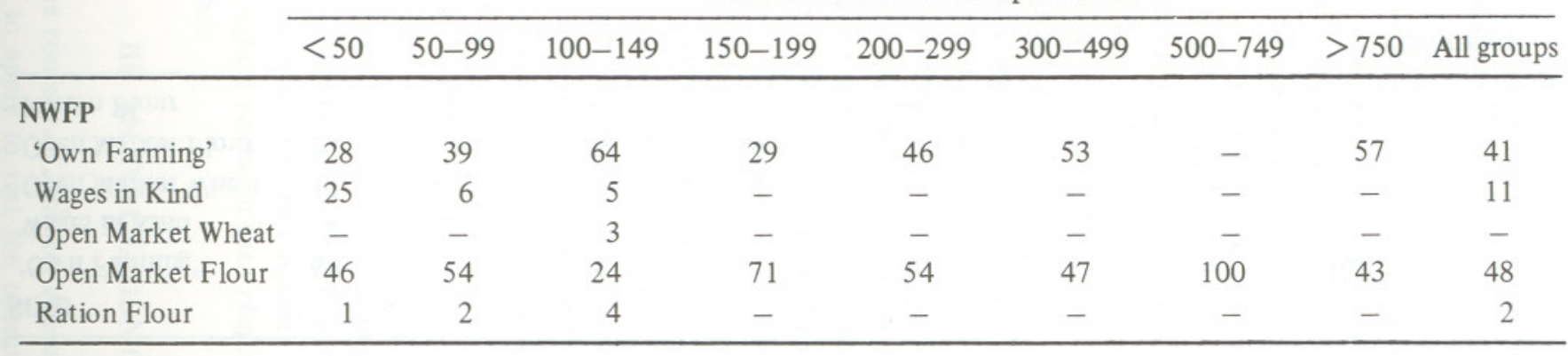

\section{B. Urban Areas}

\section{PUNJAB}

\begin{tabular}{|c|c|c|c|c|c|c|c|c|c|}
\hline 'Own Farming' & - & 10 & 17 & 13 & 23 & 27 & 43 & 4 & 20 \\
\hline Wages in Kind & - & - & 3 & 4 & - & - & - & - & 1 \\
\hline Open Market Wheat & 39 & 22 & 19 & 25 & 28 & 34 & 19 & 26 & 24 \\
\hline Open Market Flour & 44 & 30 & 24 & 31 & 22 & 23 & 23 & 28 & 27 \\
\hline Ration Flour & 17 & 38 & 37 & 27 & 27 & 16 & 15 & 1 & 28 \\
\hline \multicolumn{10}{|l|}{ SIND } \\
\hline 'Own Farming' & - & 6 & 8 & - & - & - & 30 & - & 7 \\
\hline Wages in Kind & - & - & - & - & - & - & - & - & - \\
\hline Open Market Wheat & - & 4 & - & - & 20 & - & - & - & 3 \\
\hline Open Market Flour & 65 & 33 & 51 & 70 & 50 & 82 & 60 & 85 & 52 \\
\hline Ration Flour & 35 & 57 & 41 & 30 & 30 & 18 & 10 & 15 & 38 \\
\hline
\end{tabular}

Table 3 -Continued

\begin{tabular}{|c|c|c|c|c|c|c|c|c|c|}
\hline \multicolumn{10}{|l|}{ NWFP } \\
\hline 'Own Farming' & 3 & 4 & - & - & 36 & 13 & 15 & 18 & 9 \\
\hline Wages in Kind & - & - & - & - & - & - & - & - & - \\
\hline Open Market Wheat & 5 & 1 & - & - & 5 & 2 & - & - & 2 \\
\hline Open Market Flour & 62 & 50 & 50 & 53 & 43 & 81 & 80 & 64 & 58 \\
\hline Ration Flour & 30 & 45 & 50 & 47 & 16 & 4 & 5 & 18 & 31 \\
\hline \multicolumn{10}{|c|}{ TOTAL URBAN + RURAL } \\
\hline 'Own Farming' & 34 & 45 & 57 & 51 & 54 & 57 & 58 & 49 & 50 \\
\hline Wages in Kind & 17 & 10 & 4 & 4 & 6 & 1 & 1 & - & 8 \\
\hline Open Market Wheat & 11 & 14 & 11 & 17 & 13 & 15 & 9 & 25 & 12 \\
\hline Open Market Flour & 33 & 19 & 15 & 18 & 16 & 20 & 23 & 24 & 20 \\
\hline Ration Flour & 5 & 12 & 13 & 10 & 11 & 7 & 9 & 2 & 10 \\
\hline
\end{tabular}


Table 4

Consumer Prices in Rs. per Maund as Reported by Consumers

\begin{tabular}{llcccc}
\hline Province & Area & $\begin{array}{c}\text { Open-market } \\
\text { wheat }\end{array}$ & $\begin{array}{c}\text { Open-market } \\
\text { flour }\end{array}$ & $\begin{array}{c}\text { Ration } \\
\text { flour }\end{array}$ & $\begin{array}{c}\text { Weighted } \\
\text { average }\end{array}$ \\
\hline$(1)$ & $(2)$ & $(3)$ & $(4)$ & $(5)$ & $(6)$ \\
\hline Punjab & Rural & 59.1 & 72.9 & 69.3 & 64.5 \\
& Urban & 60.2 & 74.0 & 68.8 & 67.9 \\
& & & & & \\
Sind & Rural & 61.2 & 77.9 & $73.7 *$ & \\
& Urban & 60.0 & 88.8 & 68.1 & 79.5 \\
& & & & & \\
NWFP & Rural & $*$ & 84.9 & 68.9 & 84.1 \\
& Urban & 76.8 & 88.7 & 70.2 & 82.2 \\
& & & 79.6 & 69.5 & 70.5 \\
Total & Rural & 59.5 & 81.9 & 68.6 & 72.7 \\
& Urban & 60.3 & & & \\
\hline
\end{tabular}

Source: Our Survey,

*One observation only.

parameter which expresses clearly the degree of efficiency of a market in the way in which, for example, the Gini coefficient indicates the inequality of an income distribution. The so-called price spread (defined as the difference between consumer price and producer price as a percentage of the consumer price, or, more simply, as the ratio of producer price to consumer price) is often used as an indicator of market efficiency. But it is not entirely satisfactory, if only because it says nothing about the formation of the producer price or about the cost items to be met by the difference between producer price and consumer price.

As just one parameter does not suffice to test the performance of a market, a set of criteria must be applied. Apart from the price spread, the criteria considered here are: variance of producer prices, credit ties, turnover speed, seasonal price fluctuations and adjustment to producers and consumers. ${ }^{7}$ Still other criteria, such as the number of competing traders and the concentration of trade at the village and mandi levels of trade may also be applied, but the Survey, by its nature, does not provide reliable information for this purpose. A test on the basis of the two lastmentioned criteria requires a complete coverage of trade activities in villages and market towns which a sample is not capable of. Therefore, these two criteria cannot

${ }^{7}$ For the results of an evaluation of grain markets in India using a somewhat different set of criteria, see Uma J. Lele [6]. G. Schmidt [16] applied a partly different set in his study of the agricultural markets of Chichawatni and Kamoke in (Pakistan) 1972. be applied here. Further, the difference between prices in surplus and deficit areas also provides useful information about the efficacy of a market. But at the time of the Survey the ban on interprovincial private wheat trade was still in force, with the result that a test on the basis of the available information did not make sense. A comparison of wheat and flour prices in rural and urban areas has other limitations, as will be shown below.

In the remaining part of this section the performance of private wheat traders will be discussed in terms of the criteria listed above. First the price spread. As we are concerned with private wheat trade, the prices examined here exclude prices relating to other trade channels. Thus, the prices which farmers obtain from procurement centres have been separated from the corresponding prices obtained from private traders. The latter prices (per maund) reported by farmers in the Survey are, on average, Rs. 56.2 in the Punjab, Rs. 56.9 in Sind and Rs. 70.8 in the NWFP. These figures correspond well with those reported by traders themselves. They are on average Rs. 56.2 , Rs. $57-58$ and Rs. 70.3 respectively. The first set is reproduced in Column 3 of Table 5 . The weighted averages of prices which consumers pay for wheat and flour in the open market are given in Columns 4 and 5 of the table; they correspond with the figures in Columns 3 and 4 of Table 4 . The price-spread percentages in Columns 6 and 7 indicate the ratios of producer price to consumer prices in the same province.

Table 5

Weighted Average Producer and Consumer Prices in Private Wheat Trade only in the Punjab, Sind and the NWFP in 1982

\begin{tabular}{|c|c|c|c|c|c|c|}
\hline \multirow{2}{*}{ Province } & \multirow{2}{*}{ Area } & \multirow{2}{*}{$\begin{array}{l}\text { Producer } \\
\text { Prices } \\
\text { Rs./Maund }\end{array}$} & \multicolumn{2}{|c|}{$\begin{array}{c}\text { Consumer Prices } \\
\text { Rs./Maund }\end{array}$} & \multicolumn{2}{|c|}{$\begin{array}{l}\text { Ratio of Producer Price } \\
\text { to Consumer Price } \\
\%\end{array}$} \\
\hline & & & Wheat & Flour & Wheat & Flour \\
\hline (1) & (2) & (3) & (4) & $(5)$ & (6) & (7) \\
\hline Punjab & $\begin{array}{l}\text { Rural } \\
\text { Urban }\end{array}$ & 56.2 & $\begin{array}{l}59.1 \\
60.2\end{array}$ & $\begin{array}{l}72.9 \\
74.0\end{array}$ & $\begin{array}{l}95.1 \\
93.4\end{array}$ & $\begin{array}{l}77.1 \\
75.9\end{array}$ \\
\hline Sind & $\begin{array}{l}\text { Rural } \\
\text { Urban }\end{array}$ & 56.9 & $\begin{array}{l}61.2 \\
60.0\end{array}$ & $\begin{array}{l}77.9 \\
88.8\end{array}$ & $\begin{array}{l}93.0 \\
94.8\end{array}$ & $\begin{array}{l}73.0 \\
64.1\end{array}$ \\
\hline NWFP & $\begin{array}{l}\text { Rural } \\
\text { Urban }\end{array}$ & 70.8 & $\overline{76.8}$ & $\begin{array}{l}84.9 \\
88.7\end{array}$ & $\overline{9}$. & $\begin{array}{l}83.4 \\
79.8\end{array}$ \\
\hline
\end{tabular}


Since purchases of wheat by consumers from farmers and traders occur mostly during the months directly after the harvest, the costs are relatively modest. Also the mark-ups in these transactions appear to be low. The differences between producer prices of wheat and consumer prices of flour are considerably larger. But, of course, the costs are also higher. According to the Survey, milling costs per maund in large-scale mills are, on average, Rs. 4.10 in the Punjab, Rs. 5.70 in Sind and Rs. 6.60 in the NWFP. Further, as flour is purchased throughout the year, interest and storage costs are much more important here than in the case of wheat. They may be as much as Rs. 5-7 per maund. Account must also be taken of weight loss and additional handling charges as a result of processing.

When interpreting the price spreads presented in Table 5, two considerations must be kept in mind. The price of flour in Karachi is substantially higher than in other cities of Pakistan as a result of the much higher costs of trade, transportation and storage in that megalopolis. This circumstance has a direct, negative effect on the corresponding price spread in urban Sind. On the other hand, the figures on the price spread of flour in the NWFP have an upward bias, because they relate flour prices to producer wheat prices in the same province, although more than half the volume of wheat used for this flour came from the Punjab. It was procured there by the State and subsequently released in the NWFP. Since estimates of the release prices are not available, it has not been possible for us to correct the price spreads for the NWFP. Yet, while taking account of the qualifications above, the conclusion seems warranted that trade margins in private wheat and flour trade in Pakistan are very moderate indeed. In fact, the figures on the producer-consumer price spread for wheat and flour as calculated here compare very favourably with the corresponding figures for other countries. ${ }^{8}$

We move now to a different criterion. The prices obtained by farmers in wheat sales to private traders show little variance. This observation is of importance when judging the degree of market integration. According to the Survey, an overwhelming share of the wheat sales by farmers in the Punjab in 1982 carried price tags in the range of Rs. $55-58$ per maund. The corresponding prices varied between Rs. 55 and Rs. 60 per maund in Sind and between Rs. 70 and Rs. 73 per maund in the NWFP. The latter observation shows that, also in the absence of any significant State procurement activity, producer prices remain within a restricted range. Further, the price differences within each province follow a certain pattern. There is a tendency for the wheat sold in places further away from market centres to fetch somewhat lower prices. And prices paid for small batches are, generally speaking, lower than those paid for large batches. Thus, conditions in transactions with shopkeepers are less favourable to farmers than those in transactions with beoparis and commission agents. The reason is that transaction and transportation costs per

${ }^{8}$ See Ahmed and Rustagi [1]. unit decrease with batch size. It implies, of course, that small farmers obtain, as a rule, lower prices for their marketed surplus than large farmers.

Credit ties form another criterion to judge the operation of the private wheat trade. The term applies to situations in which middlemen provide credit to farmers prior to the harvest on the condition, explicit or implicit, that the farmers shall sell to them their surplus of agricultural produce. Where such ties exist, traders hold sway over farmers and this may easily lead to unfavourable sale conditions to farmers. In reality, however, the incidence of credit ties, according to the Survey, appears to be low. Commission agents provide credit more often than other private traders, but the farmers with whom they trade are typically medium and large farmers. The danger of an unequal distribution of negotiating power is therefore limited. ${ }^{9}$

The turnover speed achieved by wheat traders provides information about their propensity to hoard wheat. The picture emerging from the Survey is quite clear on this score: buying and selling transactions are completed in rapid succession and speculative hoarding can, for all practical purposes, be ignored as a problem. As a result, the average ratio of investment in wheat trade to the volume of wheat traded is quite low; among the beoparis in the Punjab this ratio is only between Rs. 3 and Rs. 7 per maund. One of the reasons for this behaviour is the scarcity of credit among wheat traders. This also explains why traders provide credit to farmers on a very limited scale only.

It can be added here that seasonal variations in the wheat and flour prices paid by consumers are relatively small. Since 1978-79 the relative difference between top and bottom prices per year has gradually decreased to a level of about 10 percent. In some years, the difference may even have been too small to cover interest and storage costs. This is clearly another reason for the lack of attraction of speculative hoarding. In connection with the present evaluation of the private wheat trade it must be emphasized, however, that the moderate seasonal fluctuation of wheat prices must primarily be attributed to State intervention. The sheer size of the buffer stock held by the State - in recent years, approximately 45 percent of the marketed surplus - is likely to act as a passive deterrent against excessive price increments during the off-season. But the State also contributes actively to seasonal price stability, through counter-cyclical sales of procured wheat.

The adjustment of the market to farmers expresses itself mostly in the specialization of groups of wheat traders in various ranges of batch sizes. ${ }^{10}$ Among other things, it provides an opportunity to farmers with a relatively small marketable surplus - less than $950 \mathrm{~kg}$, which is the minimum quantity purchased by procurement centres - to sell their wheat. Village shopkeepers buy batches of wheat of only

${ }^{9} \mathrm{G}$. Schmidt ibid. arrives at the same conclusion. It is further supported by A. Kühn in a study of the Peshawar market system.

${ }^{10}$ This specialization is much less clear in the NWFP, however, probably as a result of the small volume of wheat traded there. 
$1-10$ maunds. For beoparis the size of the average purchase batch is 100 maunds and for commission agents it is 400 maunds. (For more details, see [4]). Trade functions must be adapted to batch sizes and it is through this adaptation that farmers with varying volumes of marketable wheat have access to the market. Table 3 shows the importance of the open market as a source of wheat and flour, especially in urban areas and for low-income groups.

The following conclusions can now be drawn. The trade functions performed by private traders in the wheat-market system of Pakistan are limited. State procurement absorbs approximately three quarters of the marketed surplus of wheat. Thus, the procurement price dominates the wheat market. For the same reason seasonal as well as long-term storage of wheat is also mainly the responsibility of the State. So the activities of private wheat and flour traders consist of collection of wheat and enlargement of batch sizes, retrograde price formation based on the procurement price, short-haul transportation, distribution of flour, and little storing and lending. But, if the evaluation in this section has any value, it can be concluded conservatively that, within this limited context, there are no signs of malfunctioning. A good share of the credit for that goes to the State.

\section{POLICY CONSIDERATIONS ${ }^{11}$}

In Pakistan, the conditions for growing wheat are very favourable, such that profitable production can be achieved with domestic prices which are significantly below world-market prices. Although this circumstance has facilitated its task enormously, the government has at least managed to avoid the serious market distortions which have led to grave problems in the food markets of other countries. The positive achievements of wheat-market policies in Pakistan, especially in the past decade, can be summed up as follows:

(i) A considerable increase in wheat production through general measures, such as promotion of fertilize use, and specific measures, such as a guaranteed price of wheat. Thus Pakistan has become, practically speaking, self-sufficient in wheat.

(ii) Reduction of price risk in wheat sales and, thus, improved income stability of farmers by means of wheat procurement at a uniform price. This procurement price is widely announced before the harvest and remains in line with the development of the general price level and of prices of other crops. (See Cornelisse and Naqvi [4, Table 1.2]).

(iii) Formation of a considerable wheat stock equivalent to approximately 45 percent of the marketed surplus.

${ }^{11}$ See Naqvi and Cornelisse [8] for a detailed discussion of the policy proposals relating to wheat and flour markets in Pakistan. (iv) Provisioning of deficit areas and importation of supplementary wheat in years of insufficient domestic supply.

(v) Low wheat and flour prices to consumers by measures which keep the producer wheat price below the international price and, for consumers of ration flour, by subsidies on the flour sold at ration shops.

(vi) Reduction of price increases during the off-season through countercyclical sales out of procured wheat.

The procurement/distribution system run by the State has been of pivotal importance in this regard. And, because several objectives deserve being maintained (e.g. those corresponding with items $\mathrm{i}$, ii, and vi above), the system can serve usefully in the future also. On the other hand, the success of wheat-market policies in terms of own production and stock formation has changed the circumstances under which the system operates. There is thus a need to review it with a view to maintaining its level of performance. Firstly, the buffer stock of wheat has now reached a size large enough to counter the effects of a poor harvest and of excessive price increases in the off-season (item iii above). Future increases in this stock can be much less than those of the past five years, so that the procurement level can be reduced accordingly. Further, in connection with item iv above, it must be noted that the ban on private wheat trade between the provinces has meanwhile been lifted. It is most likely that the differences between the prices of wheat and flour in the surplus and the deficit provinces will activate trade between these provinces, thereby further reducing the need for the State to procure wheat and ship it to deficit areas.

Finally, there are the policies regarding consumer prices of wheat and flou (item $v$ above). One important element of this - viz. the favouring of consumers vis- $d$-vis producers, and the considerable income transfer from the latter to the former which it implies - has been mentioned here, but the desirability of continuing this situation is beyond the scope of this article. But there is also the question o the design of the flour-ration system. Under the prevailing system, all family heads can apply for a ration card giving access to ration flour provided that ration shops are available in the area where they live (see Section 2). This design still reflects the concern for a general provisioning of the population in the face of a national deficit of wheat. Therefore, it does not fit the newly-gained position of self-sufficiency This does not mean that the flour-ration system can now be abolished. However, a re-orientation towards a selective system selling subsidized ration flour exclusively to the poor seems to be called for. The main argument for this is that lower-income groups in rural as well as urban areas typically depend on the market as a source of flour far more than the higher-income groups. But while markets of wheat and flou may be efficient, they do not provide compensation for the very low purchasing power of the poor. Hence, without a concessionary supply of wheat for the low income groups, the problem of malnutrition - which according to some is already acute - may be further aggravated. 
In order to establish the feasibility of a selective ration system, an estimate is needed of the volume of the procured wheat required for such a system. Table 3 shows that even the poor in rural areas depend strongly on the market for their supply of wheat and flour. Therefore, it is only reasonable to provide access to ration flour not only to the urban poor but also to the rural poor. It is true that, in principle, the present ration system is expected to extend its services to rural areas, but the reality is different, as Table 3 illustrates. An effective supply of ration flour to rural consumers thus requires a considerable adjustment of the ration system.

The amount of wheat required to run a selective flour-ration system depends also on the level of the poverty line distinguishing the target group from the rest of the population. In this excercise, this line has been drawn at a monthly per head income of Rs. 100 (Rs. of 1982) which, translated in other terms, corresponds with a monthly per household income of between Rs. 1,000 and Rs. 1,200 (Rs. of 1984). Approximately, 40 percent of the population has an income smaller than that amount. The Survey provides estimates of the amount of wheat which members of this income group obtain on average from non-market sources. This information allows calculation of the additional volume of wheat and flour required for this population group to allow a certain level of consumption per head per year. The results of such a calculation, using normative levels of wheat consumption of $130 \mathrm{~kg}$ and $140 \mathrm{~kg}$ per head per year and distinguished by province and area, are presented in Table $6{ }^{12}$ They suggest that, for a fulfilment of the norms applied here, the poor need a supply of approximately $2.2-2.6$ million tons of wheat respectively from sources other than "own farming" and "wages in kind". Evidently, the ration system does not have to take charge of this entire flow all by itself. Purchases of flour from ration shops are concentrated in the period from October to March/April, when prices in the open market tend to rise. So, if this practice continues and the ration scheme aims at a full provisioning of the lowest-income groups during seven months per year, an annual volume of 1.3 million tons or 1.5 million tons, depending on the norm adopted, would be required for the three provinces included in the calculations. Despite their rather far-reaching ambitions, these alternative schemes would exceed the estimated volume of the present system only by about 15 percent and 30 percent. Further, even if we account for the approximative nature of these calculations and for the fact that Baluchistan has been excluded, it can be concluded with some confidence that, under such a scheme, a level of procurement of approximately 2 million tons of wheat per year would allow for considerable counter-cyclical sales of wheat in the open-market. This volume of procurement also permits annual rotation of the full wheat stock. It would cut purchase activities of the State in the

${ }^{12}$ Estimates of the population in the corresponding classes of household income using the Household Income and Expenditure Survey, 1979 yield a somewhat different distribution. Yet, the total volumes of wheat(flour) calculated with this distribution practically coincide with those derived in Table 6.
Table 6

Estimates of Wheat Requirements from Market Sources by Lowest-Income Groups for Consumption of $130 \mathrm{~kg}$ and $140 \mathrm{~kg}$ per head by Province and Area: 1982

\begin{tabular}{|c|c|c|c|c|c|}
\hline \multirow[t]{2}{*}{ Area } & \multirow[t]{2}{*}{ Province } & \multirow{2}{*}{$\begin{array}{c}\text { Population } \\
\text { with income } \\
\text { of }<\text { Rs. } 100 \\
\text { per head } \\
\text { per month } \\
\text { (thousands) }\end{array}$} & \multirow{2}{*}{$\begin{array}{l}\text { Wheat from } \\
\text { 'own farming' } \\
\text { and wages } \\
\text { (kg per head) }\end{array}$} & \multicolumn{2}{|c|}{$\begin{array}{l}\text { Additional Requirements for an } \\
\text { Annual Consumption of }\end{array}$} \\
\hline & & & & $\begin{array}{l}130 \mathrm{~kg} \text { per head } \\
\text { (tons) }\end{array}$ & $\begin{array}{l}140 \mathrm{~kg} \text { per heac } \\
\text { (tons) }\end{array}$ \\
\hline \multirow[t]{3}{*}{ Urban } & Punjab & 3,370 & 10 & 404,400 & 438,100 \\
\hline & Sind & 2,520 & 5 & 315,000 & 340,200 \\
\hline & NWFP & 940 & 5 & 117,500 & 126,900 \\
\hline \multirow[t]{3}{*}{ Rural } & Punjab & 15,760 & 90 & 630,400 & 788,000 \\
\hline & Sind & 7,160 & 100 & 214,800 & 286,400 \\
\hline & NWFP & 7,570 & 60 & 529,900 & 605,600 \\
\hline Total & & 37,320 & 70 & $2,212,000$ & $2,585,200$ \\
\hline
\end{tabular}

Source: Our Survey.

wheat market by about one-third, if related to the situation in 1982-83. But the State would still absorb between 40 percent and 50 percent of the marketed surplus which guarantees a continued, firm grip on the wheat market.

Where the State retreats, private trade must step in. But the conclusion of Section 3 inspires confidence in the ability of private wheat traders in Pakistan to handle a larger share of the wheat flow efficiently. Such a move thus seems indeed feasible. It will also release public resources which can then be used for other purposes. This is an important consideration in view of the very limited room for public policies owing to the budget constraints reported in the Sixth Plan [15,pp. 41 and 42]. Yet, if a reduction of wheat procurement of the magnitude proposed here is indeed carried out, it would be best done gradually over a period of a few years. The State must also be prepared to continue its involvement in the long-haul transportation and the storage of wheat for at least some more years.

A reduction in the level of wheat procurement should not lead to a reduction in the degree of competition in the wheat market. So, procurement depots should preferably be maintained in regions where farmers find only few alternative buyers of wheat. Then, apart from any move to lower wheat purchases by the State, a reduction in the minimum batch size accepted by procurement depots may also be considered. The present minimum of $950 \mathrm{~kg}$ debars many farmers, especially small 
farmers, from direct sale to these depots. Further, it seems certainly worthwhile to heed the finding of the Punjab Wheat Disposal Survey [10] that the existence of supervisory teams and frequent visits by officials have remarkably favourable effect on various aspects of the operations of procurement centres.

The identification of the poor eligible for the purchase of ration flour in a selective system poses considerable problems in urban areas where, contrary to the situation in rural areas, social control is not very strict. The abuse of the system may be limited, if applications for ration cards are required to be accompanied by supporting statements form non-applicants. A natural selection may also be obtained if ration shops are located exclusively in districts where the poor live. But it must be admitted that a fool-proof selection cannot be achieved in the real world. Another complication lies in the differentiation between the sizes of flour rations for the rural population and those for the urban population. It appears from Table 6 that these rations can be considerably smaller in rural areas than in urban areas. But, here it will be difficult to establish boundaries between the two and to avoid abuse in regions near those boundaries.

Another adaptation of the rules of the ration system proposed here concerns the length of the interval between two purchases. If this interval is relatively long, such that the number of purchases per season is relatively small, the ration quantity per purchase must, of course, be large. Ration cardholders thus need relatively large sums of money in order to be able to buy the full ration to which they are entitled. However, people in the lowest-income groups find it very difficult to accumulate savings and this may well explain why, according to the Survey, consumers in these groups do not make full use of the prevailing ration system. It seems, therefore, that a shortening of the interval can raise significantly the efficacy of the ration system where the poorest consumers are concerned. Such a measure can also help to discourage the purchase of ration flour by non-eligible consumers who may find frequent visits to ration shops for small quantities of flour inconvenient. Finally, the Survey data also show a consistent discrepancy between the official price of ration flour and the prices reportedly paid by consumers, suggesting that ration shopkeepers overcharge their customers. In order to check such a practice it may be useful to establish supervisory committees of users and officials similar to those attached to a certain number of procurement depots.

\section{REFERENCES}

1. Ahmed, Raisuddin, and Narendra Rustagi. Agricultural Marketing and Price Incentives: A Comparative Study of African and Asian Countries. Washington D.C.: International Food Policy Research Institute. May 1984.

2. Cornelisse, Peter A. "Wheat-market Flows in the Punjab". Pakistan Development Review. Vol. XXIII, No. 1. Spring 1984. pp. 65-79.
3. Cornelisse, Peter A., and Bart Kuijpers. On the Optimum Size of a Buffer Stock - the Case of Wheat in Pakistan. Paper presented at the Second Annual General Meeting of the Pakistan Society of Development Economists. Islamabad: May 12-14, 1985.

4. Cornelisse, Peter A., and Syed Nawab Haider Naqvi. The Anatomy of the Wheat Market in Pakistan. Rotterdam: Erasmus University/Islamabad: Pakistan Institute of Development Economics. October 1984.

5. Gotsch, Carl, and Gilbert Brown. Prices and Subsidies in Pakistan Agriculture, 1960-1976. Washington, D.C.: April 1980. (World Bank Staff Working Paper No. 387)

6. Lele, Uma J. Food Grain Marketing in India, Private Performance and Public Policy. Ithaca: Cornell University Press. 1971.

7. Mellor, John W. "Food Prospects for the Developing Countries". American Economic Review. Vol. 73, No. 2. May 1983. pp. 239-243.

8. Naqvi, Syed Nawab Haider, and Peter A. Cornelisse. On Regulating Wheatmarket Activity in Pakistan. Islamabad: Pakistan Institute of Development Economics/Rotterdam: Erasmus University. 1984.

9. Opdam, J. H. M., and P. A. Cornelisse. "Wheat in Pakistan and Other Asian Countries”. Pakistan Development Review. Vol. XXI, No. 3. Autumn 1982. pp. 245-253.

10. Pakistan Agricultural Prices Commission. Punjab Wheat Disposal Survey. Islamabad. 1983. (APCOM Series No. 1)

11. Pakistan. Federal Bureau of Statistics. Household Income and Expenditure Survey 1979. Karachi. March 1983.

12. Pakistan. Finance Division. Economic Adviser's Wing. Pakistan Economic Survey, 1982-83. Islamabad. June 1983.

13. Pakistan. Finance Division. Economic Adviser's Wing. Pakistan Economic Survey, 1983-84. Islamabad. June 1984.

14. Pakistan. Ministry of Food, Agriculture and Co-operatives. Food and Agriculture Division. Agricultural Statistics of Pakistan 1982. Islamabad. August 1983.

15. Pakistan. Planning Commission. The Sixth Five Year Plan 1983-1988. Islamabad. May 1983.

16. Schmidt, G. Vermarktungssysteme für Landwirtschaftliche Produkte in Pakistan. Saarburcken: Verlag Breitenbach. 1976. 